AULA-EXPERIMENTAÇÃO COM DANÇA: demanda de um currículo-dançante

\author{
Carla Char \\ Marlucy Alves Paraíso
}

\title{
Resumo
}

$\mathrm{O}$ artigo trata dos desafios e potencialidades da criação de uma aula-experimentação com dança, para explorar os movimentos de um currículo-dançante que demandou uma conexão entre currículo, dança e desejo. Resulta de uma pesquisa experimentação em turmas do $8^{\circ}$ e $9^{\circ}$ anos do ensino fundamental de uma escola pública de Belo Horizonte, por meio de interrupções em disciplinas, usando as brechas, os intervalos entre aulas e outras oportunidades. Defende que aprender com sentido se dá no corpo em movimento e que passa por uma poética das artes do corpo entrelaçadas às palavras. Ainda, argumenta que a aula-experimentação com dança desencadeou devires, tornando possível uma aula desejante em um currículo. Após traduzir essa criação, conclui que os corpos/estudantes carregam a expressão de um desejo por viver a escola de outro modo, por meio do que compõe e transpassa um currículo-dançante. Dançam corpos e palavras.

Palavras-chave: currículo; dança; aula-experimentação

\section{EXPERIMENTATION CLASS WITH DANCE:} demand for a dancing curriculum

\begin{abstract}
The article deals with the challenges and potential of creating a dance experimentation class, to explore the movements of a dance-curriculum that demanded a connection between curriculum, dance and desire. It results from a research experimentation in classes of the 8th and 9th years of Elementary School of a public school in Belo Horizonte, through interruptions in subjects, using the gaps, the intervals between classes and other opportunities. It argues that learning with meaning takes place in the body in movement and that it passes through a poetics of the arts of the body intertwined with words. Still, it argues that the experimentation class with dance triggered becoming, making possible a desiring class in a curriculum. After translating this creation, it concludes that the bodies / students carry the expression of a desire to live the school in another way, through what they compose and pass through a dance-curriculum. Bodies and words dance.
\end{abstract}

Keywords: curriculum; dance; experimentation class

AULA-EXPERIMENTACIÓN CON DANZA: demanda de un currículum danzante

\section{Resumen}

El artículo trata sobre los desafíos y las potencialidades de la creación de una clase experimental de danza, para explorar los movimientos de un currículum-danzante que demandó una conexión entre currículum, danza y deseo. Resulta de una investigación sobre la experimentación en las clases de los grados 8 y 9 de la Escuela Primaria de una escuela pública en Belo Horizonte, a través de interrupciones en las asignaturas, utilizando los espacios vacíos, los intervalos entre clases y otras oportunidades. Sostiene que el aprendizaje con sentido tiene lugar en el cuerpo en movimiento y que pasa por una poética de las artes del cuerpo entrelazadas con las palabras. Aún así, sostiene que la clase-experimental con la danza desencadenó el devenir, haciendo posible una clase deseante en un currículum. Tras traducir esta creación, concluye que los cuerpos / alumnos portan la expresión de un deseo de vivir la escuela de otra manera, a través de lo que componen y pasan por un currículum de danza. Cuerpos y palabras bailan.

Palabras clave: currículum; danza; aula-experimentación. 


\section{Eu tô aqui pra quê? \\ Será que é pra aprender? \\ Ou será que é pra sentar, \\ me acomodar e obedecer? \\ (Estudo Errado - Gabriel, o Pensador).}

\section{ABERTURA}

Aula! Escutamos tanto sobre a aula! Aula bem planejada, mal planejada, não planejada, vazia, cheia... Aula boa, chata, ruim, tediosa, instigante, interessante, singular, marcante ${ }^{1}$. Aula expositiva, dialogada, experimental, teórica, prática, inaugural... Aula-dada, aula-clichê, aula pensada, aula desejada... Aula: tempo dedicado a estudar para aprender determinados saberes. Há quem considere que para aprender em uma aula é necessário sentar, se acomodar, obedecer. Mas aprender é sentar, acomodar e obedecer? O aprender depende de um corpo sentado, acomodado e obediente? Uma aula que requer tal postura parece não se importar com questionamentos como esses. Antes, parece querer que siga imponente e majestosa, quase intocável, e corra tudo bem, conforme os eixos estabelecidos, com tudo saindo como o planejado, do contrário, não é aula, ou é uma aula ruim.

Aula é o que enche a escola e o currículo, fazendo com que esses se voltem para a sua organização, execução e conclusão. A maior parte do tempo nas escolas é dedicada para as aulas. Se professores/as não estão em horário de aula, estão planejando, prevendo "[...] objetivos, conteúdos, atividades, recursos, avaliação" (CORAZZA, 2012, p. 24). Quando, inesperadamente, não há uma aula, esta é nomeada por aula vaga. Ou seja, ainda assim, é aula. A aula ocupa o espaço da escola e do currículo, sujeita os corpos para se adaptarem aos seus modos, exigências e rotina. Torna-se foco de atenção, de interesse, de desprezo, apreço ou desgosto. Assim, este artigo tem como objetivo mostrar como o imprevisível na experimentação de um currículo-dançante, que é uma composição entre currículo e dança, desconfigurou o que se entendia por aula e levou à criação da aula-experimentação com dança. Esta seguiu um aprender que requer sensibilidade no contato com o caos, que é o inesperado e desconhecido e, por isso, requer movimento. $\mathrm{O}$ argumento desenvolvido é o de que um currículo-dançante demandou a criação de uma aula-experimentação com dança que desencadeou devires, tornando possível uma aula desejante em um currículo.

A criação da aula-experimentação com dança é uma das demandas de um currículodançante que este artigo explora. Currículo é aqui entendido como um espaço de encontros que possibilita experimentações e movimentos. Como outros currículos que movimentam e fazem movimentar, o currículo-dançante, aqui explorado, é feito de matérias, saberes, capacidades, sentidos e dança! Distancia-se de um currículo cujo movimento é "[...] decalcado na representação", e segue "[...] um movimento de linhas dançantes" (MUNHOZ, 2016, p. 42). Trata-se de encontrar "[...] com outros corpos e, em vez de nomeá-los, mensurá-los, perder-se em linhas dançantes" (MUNHOZ, 2016, p. 42). Esse currículo é composto por aulas e pelo que lhes dá sentido. Aponta para outras possibilidades de aprender por meio da arte da dança em um currículo. É um currículo que dança e faz dançar.

Aprender é como dançar: requer paciência, treino, tentativa, insistência, encarar os erros como parte do aprender. Aprender é “[...] abrir-se à experiência com 'um outro', com 'outros', com uma coisa qualquer que desperte o desejo" (PARAÍSO, 2016, p. 209). Trata-se de "[...] uma experiência que se faz no acaso do tempo e está intimamente ligada à criação de um novo modo

1 Ver sobre isso em Corazza, 2012. 
de pensar e à potencialização de novos modos de vida" (MUNHOZ et al, 2016, p. 17). É, pois, abrir-se para se levantar, se desacomodar e até desobedecer a certas ordens impostas, para improvisar e dançar ao som de um ritmo desconhecido.

Há quem diga que dançamos por escutarmos uma música. Mas há quem diga que a música nasce de um corpo que dança (GARAUDY, 1980; MENDES, 1985). Para Dançarilha, personagem que conduz os movimentos deste artigo e da pesquisa que o fundamenta, os corpos da Escola Sagração da Primavera ${ }^{2}$ dançam de tal modo que é possível escutar a música que ecoam. Essa dança fez música, que tocou nas aulas e fez Dançarilha e estudantes dançarem. Mostrou que uma aula sem sentido para os/as estudantes e cansativa para professoras/es, pode devir uma aula musical com a dança, expressando uma qualidade dançante. Fala-se isso com base em Deleuze (1988), para quem uma aula é musical e, para Dançarilha, é uma aula movida pelo desejo de dançar. Dançarilha é um outramento da pesquisadora que fez experimentações com dança no currículo de uma escola pública da região metropolitana de Belo Horizonte/Minas Gerais, em quatro turmas do $8^{\circ}$ ano e seis turmas do $9^{\circ}$ ano do ensino fundamental, com o objetivo de criar um currículo-dançante. Para lidar com o imprevisível de um currículo-dançante, foi necessária uma criação feita na conexão entre aula, dança e desejo.

Dança é arte em movimento; é educação e um artifício para expressar desejos e para criar em um currículo. Como um currículo é um território em constante movimento, em que tudo cabe e tudo é possível, é necessário se movimentar constantemente. Desejo é o que faz movimentar os corpos porque incita a criar, a buscar viver ou ter o que se deseja. É força que faz dançar, pois desejo "[...] é fábrica, potência, alegria". Desejo é, pois, “[...] fundamental para aprender, para pensar, criar, construir, enfrentar os poderes, as dificuldades da vida, movimentar, deixar passar algo, produzir alegrias, viver" (PARAİSO, 2009, p. 278).

A aula-experimentação com dança fez Dançarilha pensar nos motivos do tédio e da indiferença em sala de aula, e a fez rever conceitos em relação a matar aula, fugir e fazer bagunça. Não seriam essas expressões de corpos-dançantes, que são corpos que desejam, que querem se movimentar, dançar, ocupar, explorar, criar? Essa aula segue os movimentos de um currículodançante, como uma música segue os movimentos de um corpo que dança. Isso porque o currículo é aqui visto como corpo, e a dança como um pensamento que movimenta o corpo (MUNHOZ, 2016). Esses são movimentos que Deleuze e Guattari (2012a) chamam de territorialização, desterritorialização e reterritorialização. $O$ processo de reterritorialização é um processo de ocupação de território. Mas este é um território movente, pois passa por movimentos que o desterritorializam, o transmutam. Nesse processo, se reterritorializa num ciclo que nunca para. É como dunas de areia que, no bater do vento, se movem e mudam suas formas.

$\mathrm{Na}$ aula-experimentação com dança ocupou-se um território de um currículo e encararamse as forças que emanavam dos corpos como oportunidades para improvisar. Improvisar é criar. É isso que este artigo buscará demonstrar explorando o que aqui se chama de movimentos. $\mathrm{O}$ Movimento 1 apresenta como Dançarilha se lança à improvisação e cria a aula-experimentação com dança. O Movimento 2 expõe que a aula-experimentação requer uma seleção, uma delimitação de território, e este é ocupado quando os corpos expressam uma qualidade dançante. O Movimento 3 aborda a paciência como uma ação de resistência na aula-experimentação com dança. Com esses movimentos este artigo afirma que corpos que bagunçam e querem matar aula podem entrar em

\footnotetext{
${ }^{2}$ Nome fictício dado à escola que foi pesquisada no período entre o final do inverno e o início da primavera. A escolha foi inspirada na icônica obra A Sagração da Primavera de Vaslav Nijinski. importante bailarino e coreógrafo dos ballets russos, do século XIX. Obra que ganhou uma versão memorável com Pina Baush, importante dançarina e coreógrafa alemã do século XX.
} 
devires, aprender e compor com a aula-experimentação com dança praticando, assim, uma auladesejante.

\section{MOVIMENTO 1: DANÇANDO COM O IMPREVISÍVEL}

Passada a primeira semana em que as experimentações com dança foram iniciadas, Dançarilha voltou à Escola Sagração da Primavera. Naquele dia, estaria novamente com quatro turmas do $9^{\circ}$ ano. Viu a possibilidade de ir com essas turmas a um espaço aberto e tanto a professora Isadora ${ }^{3}$, como a supervisora Mercedes se mobilizaram para que tivessem um espaço garantido. Dançarilha levou diferentes propostas de Improvisação, que é a criação instantânea em dança e Contato Improvisação, que é a dança que se cria no contato com outro corpo. Imaginava que, se dentro de salas de aula tão apertadas viveu bons encontros, fora de sala seria ainda melhor!

Então chegou a primeira turma, a que viu que era a mais falante e bagunceira. Isso porque aqueles corpos eram muito agitados. Falavam alto, riam, brincavam, xingavam uns aos outros e, com dificuldade, conseguia a atenção deles. Mas, mesmo em meio a essa agitação, os/as estudantes se mostravam animados/as para dançar. $\mathrm{Na}$ tarde em questão, chegaram na quadra dançando e fazendo movimentos de capoeira, sinalizando que queriam dançar. Cumprimentaram Dançarilha sorrindo e perguntaram: "o que vamos dançar hoje?"”. Então, para começar, propôs que fizessem uma roda. Mas, para seu espanto, vários/as estudantes começaram a sentar ao lado da quadra, já indicando que não iam participar. Dançarilha não forçou a participação e seguiu com quem queria. Com o passar dos minutos alguns e algumas que resistiram de início, começaram a participar da proposta inicial para aquecer os corpos.

Nessa atividade ${ }^{5}$, além de lançar e pegar uma pequena bola, Dançarilha e os/as estudantes corriam, iam ao chão, saltavam e andavam vagarosamente. Os/as estudantes se divertiram com o aquecimento porque a proposta era um jogo, algo que estão habituados a fazer na escola. Nesse jogo, quem estava com a bola tinha que correr, enquanto os/as demais andavam de maneira lenta e pesada, o que dificultava alcançar a pessoa com a bola. Esta, por sua vez, tinha que encontrar uma pessoa com o olhar e arremessar a bola para ela. Se a bola caísse no chão, todos/as tinham que se lançar no chão e tudo recomeçava com quem conseguisse pegar a bola. Caso isso não acontecesse e a pessoa fosse alcançada, formava um aglomerado de corpos em cima dessa pessoa, que tinha que fugir ou passar a bola para outra pessoa. O contrário também foi proposto: quem estava com a bola andava vagarosamente, enquanto os/as demais corriam, o que tornava a necessidade de passar a bolinha para frente, maior. Quando fez essa primeira proposta, uma estudante, que estava sentada, disse: "ficar sentada e fazer isso é a mesma coisa". Essas palavras foram como uma flecha dura que acertou Dançarilha em cheio e a entristeceu, diminuindo subitamente sua potência de agir.

Dançarilha não se deixou paralisar e passou mais três atividades que começaram bem e logo viraram uma bagunça incontrolável. Sentiu que não teve bom êxito em nenhuma dessas atividades. Um caos porque não conseguia propor mais nada. Sua garganta começou a arder. O espaço aberto,

\footnotetext{
${ }^{3}$ Os nomes da professora e da supervisora são fictícios e inspirados em artistas que criaram novas maneiras de dançar e mudaram o olhar para a dança. Mulheres que fizeram diferença na história dessa arte. Trata-se de Isadora Duncan, precursora da Dança Moderna e de Mercedes Baptista, primeira bailarina negra a integrar o corpo de baile do Theatro Municipal do Rio de Janeiro.

${ }^{4}$ Todos os trechos que mostram elementos do campo pesquisado foram extraídos dos registros no Caderno de Ensaios da Dançarilha.

${ }^{5}$ Essa proposta de aquecimento foi compartilhada por Panmella Ribeiro no III BH ImContato: Festival de Contato Improvisação de Belo Horizonte, realizado entre os dias 15 e 19 de agosto de 2018.
} 
o vento que se tornava mais forte e frio e a bagunça de pouco mais de trinta estudantes a fizeram forçar e aumentar o volume da voz. Sentiu uma frustração. Decidiu encerrar as experimentações e liberar a turma, pois o sinal estava prestes a tocar. Dançarilha sentiu as dores de uma professora da educação básica.

Enquanto a professora Isadora foi chamar a outra turma, pensou: "preciso aceitar que nem tudo convém a todos/as". Foi quando tomou a decisão de se arriscar na experimentação, deixando de lado um plano de aula que havia feito por garantia. No currículo-dançante não há como ter controle do que virá. Se Dançarilha teria o tempo todo da aula para ela, essa teria que ser, o tempo todo, uma aula-experimentação com dança que segue o ritmo da imprevisibilidade, sem "[...] regras nem soluções universais" (CORAZZA, 2012, p. 25). Deixou o vento, que batia naquela tarde fria, refrescar seus pensamentos e seguiu "[...] a linha das formas e das forças, para compreender a possibilidade do pulsar da diferença, para sentir a capacidade de transformação da tristeza e para aprender sobre a força dos devires, que pode nos inspirar na educação" (PARAÍSO, 2013, p. 54).

Chegou a outra turma e com essa sentiu, de início, uma resistência semelhante à anterior. Então propôs a atividade com a bola para aquecer os corpos. Em seguida, começou a ensinar o elemento toque, do Contato Improvisação. O toque funciona como um disparador de movimentos. Por exemplo, um/a dançarino/a apoia seu tronco ou suas mãos nas costas de outro/a dançarino/a e ambos se movimentam a partir desse contato e das sensações disparadas. Mas os/as estudantes demonstravam constrangimento em dançar desse modo. Estar na quadra implicava ter um público e sempre tinha uma turma em aula vaga. Além disso, tocar o corpo do/a outro/a era motivo para brincadeiras com tapas e socos, ou para mais constrangimento. Diante disso, Dançarilha propôs movimentos dançantes a partir de aparentes não-movimentos: estátuas. E, baseada nos estudos de Laban (1978), trabalhou com os diferentes níveis em que se pode dançar: alto, médio e baixo. Dançar no nível baixo é se movimentar no chão ou rente ao chão. Dançar no nível médio requer uma flexão dos joelhos e/ou do tronco e, dançar no nível alto, é se movimentar de pé ou saltando.

A proposta consistia em: 1) todas/os ficavam em volta de um lugar escolhido como centro. Uma pessoa por vez ia até o centro e fazia uma pose em nível alto, médio ou baixo; 2) A próxima pessoa ia ao centro e escolhia uma parte do seu corpo para apoiar no corpo da outra pessoa, trabalhando o elemento peso, mas em um nível diferente. Era necessário observar a estrutura que se formava; 3) Quando todos/as compunham aquela estrutura, deslizavam-se até o chão, saindo de um movimento estático, para um movimento fluido; 4) Feito isso, se levantavam lentamente, buscando fluência no movimento e tentavam repetir a mesma estrutura. Tratava-se de uma repetição que os/as levava a uma nova criação. Era o que Deleuze (2018) chama de repetição da diferença, pois sempre surgia algo novo. A fluência no movimento é como falar uma língua fluentemente. A movimentação segue uma continuidade. Essa movimentação não trava, não é interrompida por não saber o que fazer. Se isso ocorre, há uma quebra no fluxo.

Dançarilha nunca havia feito essa atividade. Improvisou diante dos ânimos dos corpos. Os/as estudantes gostaram e quiseram fazer mais vezes. A proposta funcionou tanto que a experimentou com outras duas turmas do $9^{\circ}$ ano naquele mesmo dia e, na mesma semana, experimentou com as turmas do $8^{\circ}$ ano. Em cada turma fluiu de uma maneira diferente, levando três estudantes do $8^{\circ}$ ano a criarem uma outra proposta de dança. O que elas sugeriram é o que na dança se chama de canon. O canon é, basicamente, fazer movimentos sequenciados em que todos dançam a mesma sequência, mas em tempos diferentes. Há diferentes maneiras de dançar em canon. No caso da proposta feita pelas estudantes, a primeira pessoa vai dançando até um determinado lugar e faz uma estátua no nível que quiser, a próxima passa pela pessoa fazendo essa mesma estátua e, em seguida, cria outra. Outra pessoa passa dançando por essas duas estátuas, 
fazendo o mesmo gesto e em seguida cria uma terceira, e assim por diante. Quando todos/as estão posicionados/as, desmancham a estátua até chegarem ao chão e começam a dançar livremente.

Ser sensível ao caos, se abrir para as mudanças e improvisar transformaram o que poderia ser um dia de maus encontros, em momentos de interação e alegria. A aula-experimentação com dança passa pelos desafios de qualquer outra aula: a instabilidade dos corpos, ora fechados, ora abertos. Trata-se de abrir mão do que impede a criação e seguir um ritmo que faz o/a professor/a experimentar (CORAZZA, 2012).

\section{MOVIMENTO 2: AULA, MATÉRIA EM MOVIMENTO}

Assim como quando se dança improvisando com a música, criando a movimentação do corpo ao sentir o toque de uma música, Dançarilha sentiu que precisava se movimentar na aulaexperimentação com dança, se movimentando pelo que a tocava a cada instante. Dançarilha desejava que, de algum modo, algo despertasse os corpos das/os estudantes, fazendo-os/as desejar dançar.

Nem todos/as queriam dançar. Dançarilha aprendeu que uma boa aula é aquela que convém, em algum momento, às/aos estudantes. Já uma aula ruim, é aquela que "[...] não convém a ninguém" (DELEUZE, 1988, s. p.) em momento algum. Assim sendo, passou a atentar ao que despertava o interesse dos/as estudantes, pois não havia nada pior do que ver estudantes entediados/as, indiferentes, surtando, fugindo e/ou frustrados com as aulas.

Aguçou os sentidos para o território em que se encontrava e, a cada experimentação, sentia movimentos que a desterritorializavam e, de súbito, a reterritorializavam. É preciso equilíbrio e, ao mesmo tempo, fazer uso do desequilíbrio para dançar nesse terreno movediço. Movimento e território estão imbricados e formam uma conexão ritmada (DELEUZE, GUATTARI, 2012b). É próprio do movimento, o ritmo; cada movimento acaba por impor um ritmo. Esses movimentos eram as constantes mudanças, os acasos, os ânimos e os imprevistos no currículo, que Dançarilha passou a ver como possibilidades para dançar.

Nesse território novo e dançante, Dançarilha parecia tatear no escuro. Como daria aulas? Quais seriam os conteúdos? O que ensinaria? Teria que examinar os documentos curriculares? Suas aulas não tinham avaliação e os/as estudantes sempre perguntavam se as atividades valeriam ponto, caso contrário, não valia a pena dançar, o que para muitos/as era o mesmo que pagar mico. Eles/as participariam das aulas? Teria que fazer planejamentos? As experimentações se reduziriam a ensaios para uma festa? Dançarilha não sabia o que fazer. Mas, mesmo com medo, tranquilizou-se dançando. Uma criança, quando com medo, busca refúgio em uma cançãozinha e "[...] ao mesmo tempo que canta, ela acelera ou diminui seu passo" (DELEUZE, GUATTARI, 2012b, p. 122). Ela dança. A dança foi a cançãozinha que a tranquilizou frente ao caos das situações inesperadas porque a fez habitar um lugar seguro. Dançarilha seguiu experimentando. Dançando, o caos começou a se organizar e começou a se sentir em casa, num processo de reterritorialização. Assim como a poesia é o lugar em que o/a poeta habita (PORPINO, 2018), a dança é um lugar onde Dançarilha habita e as aulas-experimentações seriam um lugar a habitar. Esse território a habitar, esvaziado do que Corazza (2012) nomeia por uma aula cheia de "[...] dados", que determinam "[...] conteúdo" e "[...] didática", que indicam "[...] modos de subjetivação" e o tipo de sujeito que requer, com definição de "[...] valores e critérios" e "[...] vontade de poder" e, ainda, "[...] indicam a favor de quem e do que é realizado o confronto de forças na aula" (CORAZZA, 2012, p. 24) abriu espaço para a criação da aula-experimentação com dança em meio a estudantes sobrecarregados/as e uma pesquisadoraDançarilha cheia de pressupostos em relação a saber o que fazer.

Para se sentir em casa, Dançarilha limpou todos os dados de uma aula cheia (CORAZZA, 2012), traçou um círculo, organizando “[...] um espaço limitado" (DELEUZE, GUATTARI, 
2012b, p. 122) no currículo-dançante. Dançarilha o traçou com diferentes modalidades da Dança Contemporânea. Essa escolha foi uma obra de seleção (DELEUZE, GUATTARI, 2012b), e foi a maneira que encontrou para não se perder em meio ao caos de infinitas possibilidades em um currículo. Improvisou a partir dessa delimitação, pois improvisar em uma aula não é se entregar a um laissez faire. Improvisar "[...] é ir ao encontro do Mundo, ou confundir-se com ele" (DELEUZE, GUATTARI, 2012b, p. 123). No improviso encontra-se ritmo. Isso foi, para Dançarilha, dançar em um currículo entre formas e forças (PARAÍSO, 2013).

Assim, além de experimentações com Improvisação e Contato Improvisação, passou a experimentar a Videodança - conhecida também como Video-Dança ou Dança na Tela (BRUM, 2012). Trata-se de uma dança que se faz na fusão entre Dança e Artes Visuais e só é possível contemplála na tela, o que a difere de um vídeo de dança, que é um registro de uma dança que acontece no palco ou em outros espaços. Experimentou também a Composição Coreográfica, que é o trabalho de criar uma coreografia com escolhas prévias, tanto de música, como de movimento e figurinos. Com as turmas do $9^{\circ}$ ano, experimentou a Videodança e, com as turmas do $8^{\circ}$ ano, a Composição Coreográfica. Nesse espaço delimitado, na movimentação dos corpos, as aulas devieram musicais, expressando qualidades dançantes. Essas diferentes experimentações foram maneiras de Dançarilha ensaiar e se inspirar. Isso porque uma "[...] aula quer dizer momentos de inspiração" (DELEUZE, 1988, s. p.), pois o papel do/a professor/a é inspirar (DELEUZE, 1988). Dançarilha precisou amplificar seus conhecimentos e experiências em Dança. O que não foi difícil, por se tratar de um conhecimento que ama. Para ser professor/a "[...] é preciso achar a matéria da qual tratamos, a matéria que abraçamos, fascinante", é preciso, ainda, “[...] estar totalmente impregnado do assunto e amar o assunto do qual falamos. Isso não acontece sozinho. É preciso ensaiar, preparar" (DELEUZE, 1988, s. p.).

A aula-experimentação com dança se torna musical quando emerge uma expressividade de ritmo, quando apresenta a qualidade de expressão dita dançante. Isso porque o que marca um território é o ritmo dos corpos. Marcar um território é uma ação. O currículo-dançante territorializa quando devém expressivo, quando uma prática movida no improviso devém dançante.

Uma aula-experimentação com a dança só o é quando trilha os caminhos da improvisação na busca da criação do novo. É como a improvisação na música Jazz em que se toca com base no que se sabe, mas criam-se outras melodias e ritmos que, antes da ação do tocar, seria impensável. Impensável porque não racionalizável sem o corpo, mas se faz na ação de um corpo-dançante. $\mathrm{O}$ corpo-dançante é um corpo atravessado por afectos e quando em movimentos de dança, improvisa e, do caos, cria o novo, o inédito, o inaudito. A aula-experimentação é criada no contato com o caos, de onde "[...] nascem os Meios e os Ritmos" (DELEUZE, GUATTARI, 2012b, p. 124). Nesse processo, Dançarilha dançou uma melodia outra a partir do que a afectava ${ }^{6}$. Ter pressa, não ajudaria.

Nesse dia que esteve com as turmas do $9^{\circ}$ ano, foi possível ver como Dançarilha se deparou com o caos. Quando algo a desestabilizava, recorria à sua cançãozinha, e traçava um círculo para criar um território. Mas, como se vê no movimento a seguir, logo era arremessada novamente ao caos. "O território é o produto de uma reterritorialização dos meios e dos ritmos" (DELEUZE, GUATTARI, 2012b, p. 127). Os meios e ritmos que moviam e faziam corpos mover, davam à Dançarilha uma sensação de constante perda de território. Mas há "[...] território a partir do momento em que há expressividade do ritmo. É a emergência de matérias de expressão (qualidades) que vai definir o território" (DELEUZE, GUATTARI, 2012b, p. 127). O que devinha expressão,

${ }^{6}$ Usa-se o verbo afectar por fazer referência à palavra affectio, que se refere "[...] diretamente ao corpo" (DELEUZE, 2002, p. 56). Isso porque afeto, que vem da palavra affectus, se refere “[...] diretamente ao espírito" (DELEUZE, 2002, p. 56). 
marcava um território. A qualidade ou matéria de expressão que a fazia definir um território, um chão para o dançar, era se uma experimentação devinha dançante, isto é: se ela envolvia os corpos em dança e produzia alegria, movimento, entrega.

Expressar uma qualidade dançante não se trata de desempenhar uma função de artista da dança em formação ou profissional. Trata-se de exprimir pelo corpo os blocos de sensações próprios a esta arte liberar. Essa "[...] matéria de expressão", dançante, é autônoma, ela "[...] não fica por aí. Ela passa por aí" (DELEUZE, GUATTARI, 2012b, p. 131), pois é movimento e devém estilo. Outro estilo de dança surgiu na aula-experimentação ao ritmo dos corpos, que foi a atividade com as estátuas, em que se incluíram elementos do Contato Improvisação e que se desdobrou em outra atividade fazendo uso de canons.

\section{MOVIMENTO 3: DANÇA, UM APRENDER QUE REQUER PACIÊNCIA}

\section{Enquanto o tempo acelera e pede pressa Eu me recuso faço hora vou na valsa (Paciência-Lenine).}

$\mathrm{Na}$ aula-experimentação com dança, a paciência foi uma ação de resistência a não desistir facilmente e a não deixar a tristeza e eventualidades da sala de aula parar. A paciência permitiu insistir na criação de outras saídas e encarar os desafios que sobrevinham à Dançarilha. Ser paciente é estar aberta/o a abrir mão de coisas. Mas é também insistir em algo. Isso requer também sensibilidade.

Dançarilha viveu os desafios de oferecer uma experiência com a dança a não dançarinos/as. Essa oferta demandou paciência porque nem todos/as gostam de dançar, assim como nem todos/as gostam de tocar um instrumento, cantar, atuar. Nem todos/as gostam de Português, Geografia, Matemática... É preciso ofertar e observar o que toca, o que mobiliza a diferença em cada um. Para Alvarenga (2020)7, “[...] um/a estudante da educação básica tem direito a aprender conteúdos que o/a levem a pensar nas escolhas do seu futuro profissional, incluindo a possibilidade de ser um artista". Como a dança era o conhecimento que tinha a oferecer, Dançarilha seguiu atenta aos movimentos do currículo-dançante e aprendeu a importância da paciência. Esta não é uma espera, é uma ação (PARAÍSO, 2015). Uma ação movida "[...] pela diferença, que tudo metamorfoseia, para levar vida a um currículo" (PARAÍSO, 2015, p. 52). Para isso, a paciência se torna uma qualidade para ir devagar, desacelerar, não se deixar levar pela angústia, ansiedade ou pressa. Trata-se de “[...] não se mexer demais para não espantar os devires” (DELEUZE, 2013, p. 176). É ir na valsa.

Passada uma semana, Dançarilha voltou às turmas de $9^{\circ}$ ano. Decidiu, dessa vez, ficar na sala de aula. Nos dias que antecederam sua ida à escola, encontrou-se com duas poesias e decidiu experimentar compondo dança e poesia. Trata-se da poesia Transver, de Diego Miranda e Danças, de Mário de Andrade. Ambas fazem uma relação entre vida, pensamento e dança. São essas:

TRANSVER: /v. tr./v. pron./s.m./desvario poético que acomete aqueles que tiram as palavras para dançar.

Cresço,

o que sou

em elos intangíveis.

\footnotetext{
${ }^{7}$ Fala do professor, artista, pesquisador e criador do curso de Licenciatura em Dança da Escola de Belas artes da UFMG, Arnaldo Leite de Alvarenga, durante sua terceira aula de Dança no Brasil no I Simpósio Internacional de Dança on line (SID). Em 13 jun. 2020.
} 
Comovido, como ouvido escuto o silêncio que não cala.

Sigo,

em passos firmes

outrora mancos.

Gingo,

é a vida que escorre

daqueles que correm

pelo pão - multidão.

Vivo,

morada é mundo

que transpõe as barreiras

do coração (MIRANDA, 2018, p. 11, 1-18).

\section{DANÇAS}

Quem dirá que não vivo satisfeito!

Eu danço! Dança a poeira no vendaval.

Raios solares balançam na poeira.

Calor saltita pela praça

pressa

apertos

automóveis

bamboleios

Pinchos ariscos de gritos

Bondes sapateando nos trilhos...

A moral não é roupa diária!

Sou bom só nos domingos e dias-santos!

Só nas meias o dia-santo é quotidiano!

Vida

Arame

Crimes

Quidam

cama e pança! Viva a dança!

Dança viva!

Vivedouro de alegria!

Eu danço!

Mãos e pés, músculos, cérebro...

Muito de indústria me fiz careca,

Dei um salão aos meus pensamentos!

Tudo gira,

Tudo vira,

Tudo salta,

Samba,

Valsa,

Canta,

Ri!

Quem foi que disse que não vivo satisfeito?

EU DANÇO! [...] (ANDRADE, 2013, s. p., 1-34). 
Dançarilha levou essas poesias sem saber ao certo o que faria com elas. Começou com uma roda para conversar. Estas se tornaram uma importante estratégia da aula-experimentação com a dança. Fazer rodas não é uma novidade em uma aula. Mas Dançarilha sentiu necessidade de priorizar esse momento, mesmo correndo o risco de não conseguir experimentar nada. Era um momento de conexão com os/as estudantes, “[...] de criação e manutenção de laços" (CORAZZA, 2012, p. 30), de praticar a paciência como ação.

Começou perguntando às/aos estudantes quais os tipos de artes que mais gostavam. Destacaram-se desenho, pintura, música, teatro, fotografia, circo, dança, poesia, escrita, leitura, grafite, cinema. Dançarilha leu as poesias e, depois, as escreveu no quadro. Então os/as estudantes começaram a destacar as partes que mais gostaram. No decorrer da conversa, passaram a falar sobre a vida como uma dança. Os/as estudantes ouviam atentamente e comentavam timidamente. Apesar da timidez, Dançarilha propôs que cada um expressasse com o corpo o que sentia ao ler aquelas palavras. Era um exercício para dançar e transformar a poesia em dança. Os/as estudantes travaram. A vergonha misturada com a falta de abertura dos corpos não é uma combinação que potencialize. Dançar, expressar os sentimentos com o corpo, parecia expor as pessoas.

Contudo, não interrompeu a proposta. Insistiu porque havia algo se movendo. Era preciso esperar o tempo dos/as estudantes para absorverem as poesias, para pensar, sentir e se expressarem ao mesmo tempo. Dançarilha teve que agir com paciência para não impor um ritmo que pudesse atrapalhar, dispersar e desconectar. Foi preciso esperar e agir com sutileza. Continuou conversando e perguntou o que os/as estudantes sentiam por estarem ali na escola. Ouviu respostas como: tédio, preguiça, suicídio. Perguntou se não tinha algo que gostassem na escola e um estudante respondeu: "aula diferente como a sua", e os/as demais concordaram.

Dançarilha ficou surpresa, pois no meio artístico está acostumada a ver quem gosta das suas aulas, dançar. Ali, os/as estudantes não dançaram, mas disseram gostar da aula. Algo na escola parecia matar os desejos daqueles corpos em dançar a vida, pois pareciam não conseguir se movimentar de modo sensível. Deleuze (1988, s. p.), afirma que "[...] no desejo não há morte”, há "[...] assassinato". O que tem matado o desejo desses corpos? Dançarilha pensou, com base nas respostas dos/as estudantes, que poderia ser porque a escola tem se apartado com o que dá sentido à vida. Mesmo porque, quando lhes perguntou se gostavam de artes, eles/as respondiam primeiro com um "não" porque pensavam se tratar da disciplina de Artes. Desta, a maior parte dos/as estudantes disse não gostar. Trata-se do privilégio do currículo-desempenho (PARAISO, 2015), e as Artes podem entrar nessa "fôrma" e deixar de ter sentido quando escolarizada. Mas os/as estudantes expressavam com brilho nos olhos quando falavam das artes que gostavam. Dançarilha começou a pensar se poderia haver uma conexão entre a arte dentro da escola e a arte fora da escola.

Bateu o sinal e Dançarilha foi para outra sala. Na entrada, um jovem a cumprimentou. Entrou na sala e cumprimentou a turma. Em seguida, falou sobre dança e poesia. Fez semelhante ao que havia feito na outra turma e perguntou o que sentiam ou pensavam ao ler tirar as palavras para dançar, como diz o título do poema de Diego Miranda. Alguns e algumas responderam que se tratava de cantar dançando, levaram para o sentido literal. Interagiu mais com a turma e fez a roda para conversar. Quando perguntou o que não gostavam na escola, responderam em uníssono: “aula!". O jovem que a cumprimentou quando chegou, ficou o tempo todo parado e em silêncio, no canto da sala, próximo à porta, como que à parte da aula, e lhe disse com um olhar sério: "falta diálogo, a escola não prepara para a vida, não ensina o básico, não faz relação com a vida, como você fez". Dançarilha ficou estarrecida! Isso porque, por alguns momentos, pensou que fazer uma relação entre as poesias, a dança e a vida, não tivesse surtido efeito algum, pois tinha a sensação de 
estar falando com as paredes. Mas o que aconteceu é que eles/as entraram em uma dança nômade do pensamento, dançaram sem sair do lugar.

Após esse momento, Dançarilha sentiu uma abertura e pediu para todos/as se colocarem de pé. Colocou uma música ao fundo e sugeriu que todos/as dessem as mãos. Juntos/as formaram elos, uma corrente de corpos, e o movimento de um corpo conduzia a movimentação do outro. $\mathrm{O}$ pequeno espaço da sala de aula foi redesenhado. Figuras inusitadas começaram a se formar. Figuras-movimento. Uma poesia corpórea no espaço-tempo na sala de aula. Dançavam se esforçando para não desfazer os elos da corrente que se formara. Essa corrente, aos modos da poesia de Diego Miranda, cresceu em elos tangíveis e seguiu entre passos firmes e mancos, equilibrando e desequilibrando, num esforço para não cair e desfazer os elos. Gingaram a vida que corria e escorria de seus corpos. Suaram, improvisaram, aprenderam a compor juntos. Dançarilha sentiu que, com aquela corrente, naquele instante, transpuseram as barreiras de um currículoforma8. Formaram um coração que pulsava na junção de diferentes corpos-dançantes. Tornaramse dança. Um devir-poesia!

Em seu abecedário, Deleuze diz que “[...]as pessoas têm que esperar”. Em uma aula “[...] obviamente, tem alguém meio adormecido" (DELEUZE, 1988, s. p.). Mas, esse alguém pode acordar misteriosamente "[...] no momento que lhe diz respeito" (DELEUZE, 1988, s. p.). Nesse sentido, o que pode produzir corpos-dançantes em uma aula, é o que faz alguma conexão com algo que seja do interesse desses/as estudantes. Diante de um público variado e desconhecido, desgostoso das aulas da escola, Dançarilha criou estratégias para se conectar às/aos estudantes. Nesse dia, dançaram com o corpo e com as palavras. Tiraram as palavras para dançar.

Nessa aula-experimentação com a dança, o que parecia não ter afectado os corpos, afectou. De início, o movimento corpóreo foi estático. Mas a pausa faz parte da dança. Dançarilha mudou seu ritmo. Viu que há movimento mesmo quando, aparentemente, não há. Há dança mesmo quando, aparentemente, não há. Viu que não poderia deixar o tempo de 50 minutos controlar o movimento e a vida que podem pulsar na aula-experimentação com dança pelo currículo-dançante. Viu que tinha dança ali naqueles corpos, desejo por conexão com o que dá sentido à vida.

\section{ASPIRAÇÕES}

Um dos maiores desafios na aula-experimentação com dança foi o de envolver a todos/as num dançar e num campo de conhecimento que não era contemplado na disciplina de Artes no currículo da Escola Sagração da Primavera, e estava presente apenas como linguagem da Educação Física, mas restrita a ensaios para apresentações em festas. Nesse processo, Dançarilha aprendeu que mais importante do que ver as experimentações com dança funcionando, era possibilitar que aqueles corpos sentissem um pouco de alegria, em um lugar em que o tédio, a apatia, o cansaço e a indiferença pareciam imperar. Havia uma expressão de um desejo por viver a escola de outro modo.

As/os estudantes não perdiam oportunidade de brincar, se jogar no chão, dançar funk e trap dance ${ }^{9}$, conversar, correr, rir, abraçar, jogar bola. Esses corpos pediam por movimento porque não

\footnotetext{
${ }^{8}$ Um "currículo-forma" é um currículo estático, rígido, endurecido ao que faz movimentar a vida que pulsa nos corpos de estudantes. Isso porque produz rotinas, aprisiona as forças, divide, desanima, opera com a imitação e representação, trazendo tristeza a um currículo. Um "currículo-força” é um currículo capaz de deformar as formas e de instaurar "[...] o movimento que é fundamental para o aprender" (PARAÍSO, 2013, p. 191).

9 Tanto o funk como a trap dance são danças oriundas da Cultura Hip Hop, que é composta por variadas expressões artísticas que "[...] continua se desdobrando neste exato momento em diferentes partes do globo terrestre" (SILVA, 2014, p. 17). Na escola, os/as estudantes dançavam o funk carioca, que é marcada pelos "passinhos" e movimentos sensuais, seguindo as contagiantes batidas das músicas. A trap dance é uma dança que se faz ao som do ritmo trap, um
}

Revista Teias v. 21 • n. 63• out./dez. 2020 • Seção Temática Docência, currículo, didática, aula: fantástico arquivo político da diferença 
parece haver sentido num corpo estático, quieto e sério. Não parece haver sentido ficar horas sentados/as em carteiras apertadas, em silêncio, aprendendo matérias que não lhes fazem sentido no presente. Aguentam porque, num futuro próximo, entenderão o porquê daquele conhecimento todo no decorrer de anos. O currículo profissional, do futuro, os faz aguentar, à revelia, as dores e angústias do currículo-forma do presente. Mas a força que pulsa, vibra e ecoa desses corposdançantes parece pedir mais. Pede por um currículo-dançante: um aprender com sentido, que se dá no corpo em movimento e que passa por uma poética das artes do corpo. Pede por uma aula que "[...] transforma o desejo e transmuta a crueldade" (CORAZZA, 2012, p. 31). Esses corpos na escola são vida que pulsa e deseja e, por isso, podem mais do que sentar, acomodar e obedecer. São corpos-dançantes. Daí a necessidade de "[...] praticar um currículo simplesmente por um desejo de manter-se vivo" (MUNHOZ, 2016, p. 47).

Nas aulas-experimentação com dança Dançarilha viu que os corpos que bagunçam, que se mostram entediados e agitados parecem estar em um devir-animal, posto que um "[...] animal, farto da imobilidade imposta, evade-se, bufa, fugindo de uma sensação e não de uma coisa" (VALÉRY, 2012, p. 28). Nesse sentido, os corpos dos/as estudantes fugiam da sensação de aprisionamento, de enjaulamento da potência do corpo. Um dos estudantes relatou: "A gente fica igual cachorro lá dentro. A gente não pode nem sair pra beber água. Mó chato!”.

As travessuras, os estopins de violência e até agressão podem ser resultado disso, já que o corpo farto da imobilidade "[...] extravasa-se em galope e travessuras" (VALÉRY, 2012, p. 29. Destaque do autor). Mas há uma "[...] potência superabundante" (VALÉRY, 2012, p. 29) nos corpos que pede por liberação. Há uma necessidade de expressão dessa potência. A dança pode entrar no lugar dessa liberação de potência e não para enfatizar uma disciplinarização que poda os desejos, potencialidades e anula a diferença. Isso porque o corpo que dança transgride: uma aula cheia (CORAZZA, 2012); uma visão de um aprender dicotomizado; uma educação pautada no conteudismo, no racionalismo e na lógica; uma estrutura que faz sentar; o que se entende por dança em um currículo; e o que se entende por aula, tradicionalmente.

Os movimentos acima evidenciam que a aula-experimentação com dança é um convite para dançar com a imprevisibilidade em um currículo, a aprender a exercitar a paciência como ação, buscando uma conexão com diferentes corpos. Essa aula possibilitou que um pouco de raio de sol, de gotas de chuva atravessassem o guarda-chuva rígido do currículo-forma. Trata-se de um equilíbrio ao desafiar as intempéries do caos que atravessam a vida e o currículo. A aulaexperimentação com dança segue por esses caminhos tempestuosos, abre brechas para o desejo e faz corpos devirem corpos-dançantes. A aula-experimentação com dança é uma aula-dançante e é também uma aula desejante.

estilo de música do Hip Hop, que mistura diferentes batidas da música eletrônica. Um estilo que vem crescendo desde os anos 2000, especialmente com o advento das redes sociais e, com ela, surgiu uma outra maneira de dançar, que mistura movimentos coreografados e de improviso, podendo combinar diferentes estilos das diferentes danças da Cultura Hip Hop. 


\section{REFERÊNCIAS}

ANDRADE, Mário de. Poesias completas. v. 1. Rio de Janeiro: Nova Fronteira, 2013.

BRUM, Leonel B. Videodança: uma escrita cênica da dança. 181p. Tese, Programa de Pós-graduação em Artes Visuais. Doutorado em Artes Visuais, Escola de Belas Artes, Universidade Federal do Rio de Janeiro, UFRJ, Rio de Janeiro, 2012.

CORAZZA, Sandra Mara. Didaticário de criação: aula cheia. 1. ed. Porto Alegre: UFRGS, 2012.

DELEUZE, Gilles. O abecedário de Gilles Deleuze. Transcrição integral do vídeo para fins exclusivamente didáticos. 1988. Disponível em http://escolanomade.org/wpcontent/downloads/deleuze-o-abecedario.pdf . Acesso em 2 ago. 2020.

DELEUZE, Gilles. Espinosa: filosofia prática. Tradução Daniel Lins e Fabien Pascal Lins. São Paulo: Escuta Editora, 2002.

DELEUZE, Gilles. Conversações. Tradução Peter Pál Pelbart. 3. ed. Rio de Janeiro: Editora 34, 2013.

DELEUZE, Gilles. Diferença e repetição. Tradução Luis Orlandi e Roberto Machado. 1. ed. Rio de Janeiro, São Paulo: Paz e Terra, 2018.

DELEUZE, Gilles; GUATTARI, Félix. Mil Platôs: capitalismo e esquizofrenia 2, v. 5. 2. ed. Tradução Peter Pál Pelbart e Janice Caiafa. São Paulo: Editora 34, 2012a.

DELEUZE, Gilles; GUATTARI, Félix. Mil Platôs: capitalismo e esquizofrenia 2, v. 4. 2. ed. Tradução Suely Rolnik São Paulo: Editora 34, 2012b.

GARAUDY, Roger. Dançar a vida. 3. ed. Rio de Janeiro: Nova Fronteira, 1980.

LABAN, Rudolf. Dominio do movimento. Tradução: Anna Maria Barros De Vecchi e Maria Sílvia Mourão Netto. 5. ed. São Paulo: Summus, 1978.

MENDES, Miriam G. A dança. São Paulo: Ática, 1985.

MIRANDA, Diego. Ensaio poético sobre a teoria das coisas. São José dos Campos: Diversos somos todos, 2018.

MUNHOZ, Angélica V. Currículo entre linhas dançantes. In: MUNHOZ, Angélica V.; COSTA, Cristiano B. da; OHLWEILER, Mariane I. (orgs.). Curriculo, espaço, movimento: notas de pesquisa. Lajeado: Ed. Univates, 2016, p. 41-48.

MUNHOZ, Angélica V. et al. Aprender no encontro com o mestre. In: MUNHOZ, Angélica V.; COSTA, Cristiano B. da; OHLWEILER, Mariane I. (orgs.). Curriculo, espaço, movimento: notas de pesquisa. Lajeado: Ed. Univates, 2016, p. 7-18.

PORPINO, Karenine de Oliveira. Dança é educação: interfaces entre corporeidade e estética. 2. ed. Natal, Rio Grande do Norte: EDUFRN, 2018. 140p.: il., PDF; 7.3 Mb. Disponível em http://repositorio.ufrn.br/. Acesso em 21 jun. 2020.

PARAÍSO, Marlucy. Currículo, desejo e experiência. Educaşão \& Realidade (UFRGS), Porto Alegre, v. 34, p. 277-293, 2009.

PARAÍSO, Marlucy A. Um currículo entre formas e forças: diferença, devir-artista da contadora de filmes e possibilidades de alegria em um currículo. In: FAVACHO, André M. P; PACHECO, José A.; SALES, Shirlei R. (orgs.). Currículo, conhecimento e avaliação: divergências e tensões. Curitiba: Editora CRV, 2013, p. 191-207.

PARAÍSO, Marlucy A. Currículo nômade: quando os devires fazem a diferença proliferar. KIRCHOF, Edgar R.; WORTMANN, Maria Lúcia; COSTA, Marisa V. (orgs.). Estudos culturais e 
educação contingências: articulações, aventuras, dispersões. 1. ed. Canoas: Ed. ULBRA, v. 1, p. 269288, 2015.

PARAISO, Marlucy Alves. Currículo e relações de gênero: entre o que se ensina e o que se pode aprender. Revista Linhas. Florianópolis, v. 17, n. 33, p. 194-225, jan./abr. 2016.

SILVA, Ana Cristina R. Dança de rua: do ser competitivo ao artista da cena. 269f. Dissertação, Teatro, Dança, Performance. Mestrado em Artes da Cena, Universidade Estadual de Campinas, Campinas, 2014.

VALÉRY, Paul. Degas dança desenho. Trad. Christina Murachco e Célia Euvaldo. 1. ed. São Paulo: Cosac Naify, 2012.

\section{Informações das autoras}

Carla Char

Faculdade de Educação / Universidade Federal de Minas Gerais

E-mail: carlacharmes@gmail.com

ORCID: https://orcid.org/0000-0001-6042-0726

Link Lattes: http://lattes.cnpq.br/4048206526141496

Marlucy Alves Paraíso

Faculdade de Educação / Universidade Federal de Minas Gerais

E-mail: marlucyparaiso@gmail.com

ORCID: http://orcid.org/0000-0002-3542-4650

Link Lattes: http://lattes.cnpq.br/4839214907972946 